\title{
Chemo-Herbal Potentials of Fractionalized Extract of Mimosa pudica in Cadmium-Induced Hepatocellular Tumor with Associated Alpha-Fetoprotein and Gamma-Glutamyl Transferase Elevation
}

\author{
Onyije Felix Monday ${ }^{1}$, Newyear Patience Ekiokakpo르, Ezeiraku Ferdinand Chukwuma ${ }^{1}$, \\ Mgbere Osaro Obari ${ }^{2}$ \\ ${ }^{1}$ Department of Medical Laboratory Science, Faculty of Basic Medical Sciences, College of Health Sciences, \\ Niger Delta University, Wilberforce Island, PMB 071, Bayelsa State, Nigeria \\ ${ }^{2}$ Department of Pharmaceutical Health Outcomes \& Policy, College of Pharmacy, University of Houston, \\ Texas Medical Center, Houston, Texas, USA
}

\author{
SUMMARY
}

The plant Mimosa pudica (M. pudica) has been reported by researchers as an anti-inflammatory herb, amongst other properties, but its use as an anticancer herb is still sketchy. This study was aimed at evaluating the $\mathrm{n}$-hexane, butanol and aqueous fractions of $M$. pudica leaf extract as a chemo-herbal therapy in cadmium-induced hepatocellular tumor. Forty-five $(n=45)$ adult rats of Sprague Dawley strian were used for this research. The rats were randomly assigned into nine different clusters (groups A-I), of five rats of Sprague Dawley strain each; hepatocellular tumor was induced using $0.4 \mathrm{mg} / \mathrm{ml}$ cadmium administered through drinking water to groups B-I for 50 days. M. pudica fractionalized extracts were administered orally at the dose of $25 \mathrm{mg} / \mathrm{kg}$ and $50 \mathrm{mg} / \mathrm{kg}$ to groups $\mathrm{D}$ and I for 14 days, respectively. Meanwhile, group C received $2.5 \mathrm{mg} / \mathrm{kg}$ of Mesotheroxate (standard cancer drug) for $\mathbf{1 0}$ days. Histological slides for groups C-I showed a notable histomorhological improvement in liver tissue as well as markedly reduced degeneration when compared with the damage control group (group B). The AST, ALT, ALP, $\gamma$ GT and AFP levels in group B $(285.30 \pm 4.61 \mathrm{IU} / 1,137.30 \pm 12.72 \mathrm{IU} / 1,424.70 \pm 33.5 \mathrm{IU} / 1,6.80 \pm$ $0.26 \mathrm{IU} / 1$ and $1.82 \pm 0.28 \mathrm{ng} / \mathrm{ml}$, respectively) were significantly increased $(\mathrm{p}<0.05)$ when compared to the control group values $(123.30 \pm 5.81 \mathrm{IU} / \mathrm{l}, 85.33 \pm 2.40 \mathrm{IU} / \mathrm{l}, 253.70 \pm 4.91 \mathrm{IU} / \mathrm{l}, 0.96 \pm 0.35 \mathrm{IU} / 1$ and $0.37 \pm 0.05 \mathrm{ng} / \mathrm{ml})$ and other treated groups. This study reveals that $M$. pudica demonstrated some prospective anti-carcinogenic activity. Hence, it could be used as a potential chemo-herbal therapy.

Key words: chemo-herbal, hepatocellular tumor, Mimosa pudica, mitotically active cell, cancer 


\section{INTRODUCTION}

The use of herbal medicines by humans for treatment of various diseases predates written history. The major reason for cancer treatment is to achieve palliation where cure is out of reach. Research has shown that only $30 \%$ of all cancers are cured routinely (1). Plants with anticancer properties have been acknowledged for centuries now. The National Cancer Institute (NCI) has screened approximately 35,000 plant species for potential anticancer activities. Among them, about 3,000 plant species have demonstrated reproducible anticancer activity (2). Natural products are the most important anti-cancer agents and approximately three quarters of anti-tumor compounds used in medicine are natural products or related to them (3).

Mimosa pudica (M. pudica) has a rapid movement and undergoes changes in the orientation of its leaf, which is called nyctinastic movement or "sleep". The foliage closes during darkness and reopens in light (4). The leaflets also close when stimulated by touch, warmth, shaking or blowing (5). Mimosa pudica has an anticancer alkaloid, and phytochemical studies of this plant reveal the presence of nor-epinephrine, $\alpha$-pinitol, $\beta$-sitosterol, mimosine and 5, 7, 4-trihdroxyl 8-C-[alpha-L-rhamnopyranosyl-(-2)]-beta-D glucopyranosylflavone $(6,7)$. Other researchers have reported on its antioxidant, antibacterial, antifungal, anti-inflammatory, hepatoprotective, antinociceptive, anticonvulsant, antidepressant, antidiarrheal, hypolipidemic activities, as well as diuretic, antiparasitic, antimalarial, and hypoglycemic properties which have been attributed to different parts of the plant and forms of use (8-14); how-ever, its use as an anticancer herb is still sketchy. Hence, this study was aimed at evaluating the fractionalized leaf extracts of $M$. pudica as a chemo-herbal therapy in cadmium-induced hepatocellular tumor.

\section{MATERIAL AND METHODS}

\section{Animals}

Forty-five adult Sprague Dawley rats weighing an average of $185 \mathrm{~g}$ were used for this study. The animals were obtained from the Department of Pharmacology, Faculty of Basic Medical Sciences, College of Health Sciences, Niger Delta University, Wilberforce Island, Bayelsa State of Nigeria. The Sprague Dawley rats were randomly distributed into nine clusters (groups AI), 5 rats each, and were placed in their respective cages. The cages were made up of aluminum frame with metal net-tings, and a plastic base and a cover. The Sprague Dawley rats were allowed to acclimatize for one week. They were fed growers mash manufactured by Grand cereals limited, Jos, plateau state, Nigeria. Water was provided ad libitum. The Sprague Dawley rats were exposed to natural lighting condition (12-hour light-dark cycle) and room temperature, and were handled in accordance to standard protocols and guidelines for the care, treatment and use of laboratory animals for research (National Ins-titute of Health).

\section{Cadmium chloride}

Cadmium chloride hemihydrate with batch number GB/T 1285-94 XK 13-201000130, CN: 61504 manufactured by Xilong Scientific cooperation limited, China was used to induce a hepatocellular tumor.

\section{Plant collection, extraction and fractionali- zation}

A bulk of fresh M. pudica leaves used for this study was collected in the month of June, 2017 from different axis of the Garden city, Rivers State, Nigeria, located between latitude $50601 \mathrm{~W}$ and longitude 60101 E. The plant was authenticated and deposited with voucher number NDUP210 at herbarium of the Department of Pharmacognosy and Herbal Medicine, in the above mentioned University. The leaves of $M$. pudica were dried in an oven for $300 \mathrm{C}$ for 4 days, and thereafter pulverized to coarse powder weighing $893 \mathrm{~g}$. The powder was macerated in ethanol for 72 hours. The concentrated etha-nol extracts were further subjected to partial fractionation with solvents of increasing polarity using n-hexane, butanol and aqueous fractions.

\section{Experimental design}

Forty-five ( $\mathrm{n}=45)$ adult male Sprague Dawley rats weighing an average of $185 \mathrm{~g}$ were randomly distributed into nine groups of five animals each. Group A served as a normal control, group B served as a damage control. Groups B-I were treated with cadmium chloride $(0.4 \mathrm{mg} / \mathrm{ml})$ for 50 days, after which group $\mathrm{C}$ was treated for 10 days with $2.5 \mathrm{mg}$ of Mesotheroxate and groups DI were treated using an oral gastric tube for 14 days. The layout of the treatment groups was as follows:

Group A - Control (water ad libitum)

Group B - CdCl2 $0.4 \mathrm{mg} / \mathrm{ml}$

Group C - CdCl2 $0.4 \mathrm{mg} / \mathrm{ml}+$ Mesotheroxate (2.5mg) 
Group D - $\mathrm{CdCl} 20.4 \mathrm{mg} / \mathrm{ml}+\mathrm{N}-\mathrm{Hexane}$ fraction of M. Pudica $(25 \mathrm{mg} / \mathrm{Kg})$

Group E - CdCl2 $0.4 \mathrm{mg} / \mathrm{ml}+\mathrm{N}-\mathrm{Hexane}$ fraction of M. Pudica $(50 \mathrm{mg} / \mathrm{Kg})$

Group F - CdCl2 $0.4 \mathrm{mg} / \mathrm{ml}+$ butanol fraction of $M$. Pudica $(25 \mathrm{mg} / \mathrm{Kg})$

Group G - CdCl2 $0.4 \mathrm{mg} / \mathrm{ml}$ + butanol fraction of $M$. Pudica $(50 \mathrm{mg} / \mathrm{Kg})$

Group $\mathrm{H}-\mathrm{CdCl} 20.4 \mathrm{mg} / \mathrm{ml}$ +aqueous fraction of $M$. Pudica $(25 \mathrm{mg} / \mathrm{Kg})$

Group I - CdCl2 $0.4 \mathrm{mg} / \mathrm{ml}+$ aqueous fraction of $M$. Pudica $(50 \mathrm{mg} / \mathrm{Kg})$

\section{Biochemical studies}

Animals from the different treatment groups were sacrificed and blood samples were collected immediately through the jugular vein and placed in plain sample bottles. The samples were allowed to clot for about 30 minutes and then centrifuged at $3000 \mathrm{rpm}$ for $15 \mathrm{minu}-$ tes. The resultant supernatants (serum) were aliquoted and stored in the refrigerator at $-20{ }^{\circ} \mathrm{C}$ for biochemical analysis of aspartate aminotransferase (AST), alanine aminotransferase (ALT), alkaline phosphatase (ALP) and gamma-glutamyltransferase $(\gamma \mathrm{GT})$. These biochemical parameters were determined using SELETRA PRO $S$ chemistry analyzer manufac-tured by ELITech Group.

The alpha-feto protein (AFP) was analyzed using the Accu@Bind Elisa Test system method for the determination of hepatocellular tumor. In 1996, Henry JB stated that AFP is the most useful marker in the diagnosis and management of hepatocellular carcinoma (15).

\section{Histological study}

The rats in group A and B were sacrificed after the $50^{\text {th }}$ day, while rats in groups C-I were sacrificed after treatment on the $65^{\text {th }}$ day, using chloroform inhalation method. The liver of each animal of control and treated groups were collected and fixation was carried out in $10 \%$ formal saline fixative for twenty-four hours. The tissues were processed through dehydration, clearing and impregnation, using automatic tissue processor Histokinette (LEICA TP 1020). The tissues were embedded in paraffin wax in tissue embedder (LEICA EG 1160 ), trimmed and sectioned in a rotary microtome (LEICA RM 2125 RTS) with gauge set at 20 and 5 microns thickness, respectively. The tissues were further attached to grease free slides and afterward dewaxed in xylene and stained using haematoxylin and eosin to de- monstrate the general tissue structure (16). The stained slides were examined using a bright field light compound microscope at $x 100$ magnifications.

\section{Statistical analysis}

The data obtained were analyzed using one-way analysis of variance (ANOVA) and the means ( \pm standard error of mean) were compared with each other using Dunnett's Multiple Comparison Test. The probability value of 0.05 was considered significant. Statistical analysis were performed using the JMP statistical discovery $^{\mathrm{TM}}$ software version 12.1 (SAS Institute, Cary, NC, USA).

\section{RESULTS}

\section{Biochemical parameters}

The biochemical parameters of the experimental animals by treatment group is given in Table 1. AST was significantly increased $(\mathrm{p}<0.05)$ in groups $\mathrm{B}, \mathrm{F}$ and $\mathrm{H}$ $(285.30 \pm 4.61 \mathrm{IU} / \mathrm{l}, 206.00 \pm 40.38 \mathrm{IU} / \mathrm{l}$ and $211.30 \pm 16.90$ $\mathrm{IU} / \mathrm{l})$, respectively, when compared to the control group A $(123.30+5.81 \mathrm{IU} / \mathrm{l})$. However, there was no significant $(\mathrm{p}>$ $0.05)$ difference between groups C, D, E, G and I (173.70 \pm 2 $8.99 \mathrm{IU} / \mathrm{l}, 170.00 \pm 29.50 \mathrm{IU} / \mathrm{l}, 158.00 \pm 13.65 \mathrm{IU} / \mathrm{l}, 162.00 \pm$ 11.14 and $160.00 \pm 21.59 \mathrm{IU} / \mathrm{l}$, respectively) and the control group $(123.30+5.81 \mathrm{IU} / \mathrm{l})$. Although ALT increased significantly $(\mathrm{p}<0.05)$ in group B $(137.30 \pm 12.72 \mathrm{IU} / \mathrm{l})$ when compared to the control group $(85.33 \pm 2.40 \mathrm{IU} / \mathrm{l})$, we observed no significant $(\mathrm{p}>0.05)$ difference in ALT in groups C-I $(93.67 \pm 2.40 \mathrm{IU} / \mathrm{l}, 67.33 \pm 10.35 \mathrm{IU} / \mathrm{l}, 58.33 \pm 10.93 \mathrm{IU} / \mathrm{l}$, $76.33 \pm 6.17 \mathrm{IU} / \mathrm{l}, 70.67 \pm 5.20 \mathrm{IU} / \mathrm{l}, 81.67 \pm 10.53 \mathrm{IU} / \mathrm{l}$ and $73.33 \pm 1.76 \mathrm{IU} / \mathrm{l}$, respectively) and the control group. Similarly, ALP (424.70 $\pm 33.53 \mathrm{IU} / \mathrm{l})$ and $\gamma \mathrm{GT}(6.80 \pm 0.26 \mathrm{IU} / \mathrm{l})$ also increased significantly $(\mathrm{p}<0.05)$ in group $\mathrm{B}$, while other groups (C- I) [ALP $(279.30 \pm 52.19$ IU/l, $259.30 \pm 8.68$ $\mathrm{IU} / \mathrm{l}, 252.70 \pm 6.64 \mathrm{IU} / \mathrm{l}, 239.70 \pm 14.88 \mathrm{IU} / \mathrm{l}, 247.70 \mathrm{I} \pm 24.44$ $\mathrm{IU} / 1,263.00 \pm 13.01 \mathrm{IU} / \mathrm{l}$ and $225.70 \pm 2.02 \mathrm{IU} / \mathrm{l}$, respectively) and $\gamma \mathrm{GT}(5.76 \pm 0.31 \mathrm{IU} / \mathrm{l}, 1.06 \pm 0.37 \mathrm{IU} / \mathrm{l}, 3.07 \pm 2.96 \mathrm{IU} / \mathrm{l}$, $0.57 \pm 0.33 \mathrm{IU} / \mathrm{l}, 0.46 \pm 0.38 \mathrm{IU} / \mathrm{l}, 1.06 \pm 0.21 \mathrm{IU} / \mathrm{l}$ and $0.66 \pm$ $0.27 \mathrm{IU} / \mathrm{l}$, respectively] were not significant $(\mathrm{p}>0.05)$ when compared with the controls $(253.70 \pm 4.91 \mathrm{IU} / 1$ and $0.96 \pm$ $0.35 \mathrm{IU} / \mathrm{l})$, but were significant $(\mathrm{p}<0.05)$ when compared to group B.

Graph 1 shows the alpha feto protein in the experimental animals by treatment group. In the same vein, serum alpha feto protein was increased in group B (1.82 \pm $0.28 \mathrm{ng} / \mathrm{ml})$ when compared to the control $(0.37 \pm 0.05$ $\mathrm{ng} / \mathrm{ml})$ and other treatment groups C-I $(0.54 \pm 0.23 \mathrm{ng} / \mathrm{ml}$, 
$0.34 \pm 0.14 \mathrm{ng} / \mathrm{ml}, 0.12 \pm 0.03 \mathrm{ng} / \mathrm{ml}, 0.27 \pm 0.08 \mathrm{ng} / \mathrm{ml}, 0.19$ $\pm 0.04 \mathrm{ng} / \mathrm{ml}, 0.24 \pm 0.03 \mathrm{ng} / \mathrm{ml}$ and $0.28 \pm 0.07 \mathrm{ng} / \mathrm{ml}$ ).

\section{Histopathological studies}

Figure 1 shows the photomicrograph of the liver of group A (control) with normal central vein, with well radiating hepatocytes and sinusoids. Group B representative slide is characterized by mixed inflammatory and mitotically active cells and periportal necrosis. Groups C, $\mathrm{D}, \mathrm{E}$ and $\mathrm{F}$ show heavy infiltration of inflammatory cells, while group $\mathrm{H}$ shows degenerating and necrotic liver stroma. However, groups $\mathrm{G}$ and I are similar to the control.

Table 1. Biochemical parameters of experimental animals by treatment group

\begin{tabular}{l|c|c|c|c}
\hline \hline \multirow{2}{*}{ Treatment } & AST (IU/l) & ALT (IU/l) & ALP (IU/l) & $\gamma$ GT(IU/l) \\
\cline { 2 - 5 } & Mean \pm SEM & Mean \pm SEM & Mean \pm SEM & Mean \pm SEM \\
\hline Group A & $123.30 \pm 5.81^{\mathrm{a}}$ & $85.33 \pm 2.40^{\mathrm{a}}$ & $253.70 \pm 4.91^{\mathrm{a}}$ & $0.96 \pm 0.35^{\mathrm{a}}$ \\
Group B & $285.30 \pm 4.61^{\mathrm{ab}}$ & $137.30 \pm 12.72^{\mathrm{b}}$ & $424.70 \pm 33.53^{\mathrm{b}}$ & $6.80 \pm 0.26^{\mathrm{b}}$ \\
Group C & $173.70 \pm 28.99^{\mathrm{a}}$ & $93.67 \pm 2.40^{\mathrm{a}}$ & $279.30 \pm 52.19^{\mathrm{a}}$ & $5.76 \pm 0.31^{\mathrm{a}}$ \\
Group D & $170.00 \pm 29.50^{\mathrm{a}}$ & $67.33 \pm 10.35^{\mathrm{a}}$ & $259.30 \pm 8.68^{\mathrm{a}}$ & $1.06 \pm 0.37^{\mathrm{a}}$ \\
Group E & $158.00 \pm 13.65^{\mathrm{a}}$ & $58.33 \pm 10.93^{\mathrm{a}}$ & $252.70 \pm 6.64^{\mathrm{a}}$ & $3.07 \pm 2.96^{\mathrm{a}}$ \\
Group F & $206.00 \pm 40.38^{\mathrm{ab}}$ & $76.33 \pm 6.17^{\mathrm{a}}$ & $239.70 \pm 14.88^{\mathrm{a}}$ & $0.57 \pm 0.33^{\mathrm{a}}$ \\
Group G & $162.00 \pm 11.14^{\mathrm{a}}$ & $70.67 \pm 5.20^{\mathrm{a}}$ & $247.70 \pm 24.44^{\mathrm{a}}$ & $0.46 \pm 0.38^{\mathrm{a}}$ \\
Group H & $211.30 \pm 16.90^{\mathrm{ab}}$ & $81.67 \pm 10.53^{\mathrm{a}}$ & $263.00 \pm 13.01^{\mathrm{a}}$ & $1.06 \pm 0.21^{\mathrm{a}}$ \\
Group I & $160.00 \pm 21.59^{\mathrm{a}}$ & $73.33 \pm 1.76^{\mathrm{a}}$ & $225.70 \pm 2.02^{\mathrm{a}}$ & $0.66 \pm 0.27^{\mathrm{a}}$ \\
\hline \hline
\end{tabular}

SEM=Standard error of mean; within each parameter, means \pm SEM with different superscripts $(a, b$ and $a b)$ are significantly different at $\mathrm{p}<0.05$. Treatment groups: Group $\mathrm{A}=$ Normal control; Group B $=$ Damage control (Cadmium chloride); Group C= Methotrexate; Group D = N-Hexane fraction $(25 \mathrm{mg} / \mathrm{kg})$; Group E= N-Hexane fraction (50mg/kg); Group F= Butanol fraction (25mg/kg); Group G= Butanol fraction (50mg/kg); Group H=Aqueous fraction (25mg $/ \mathrm{kg})$; Group I = Aqueous fraction $(50 \mathrm{mg} / \mathrm{kg})$.

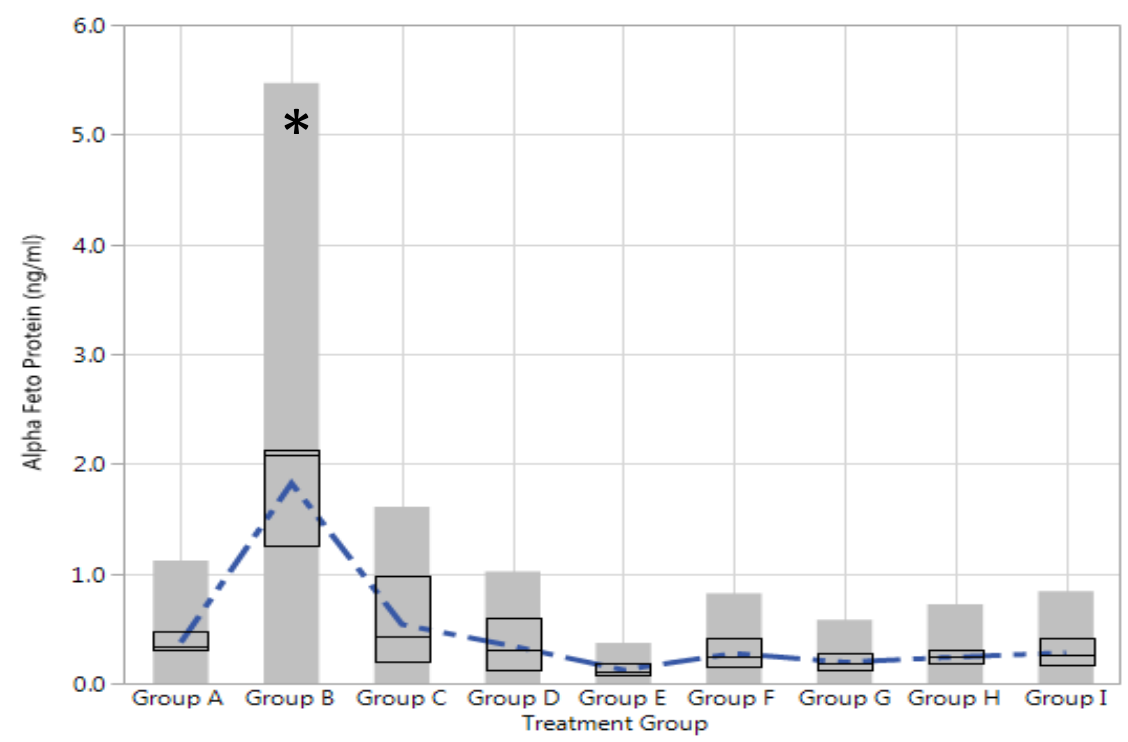

Graph 1. Alpha-feto protein $(\mathrm{ng} / \mathrm{ml})$ in experimental animals by treatment group 

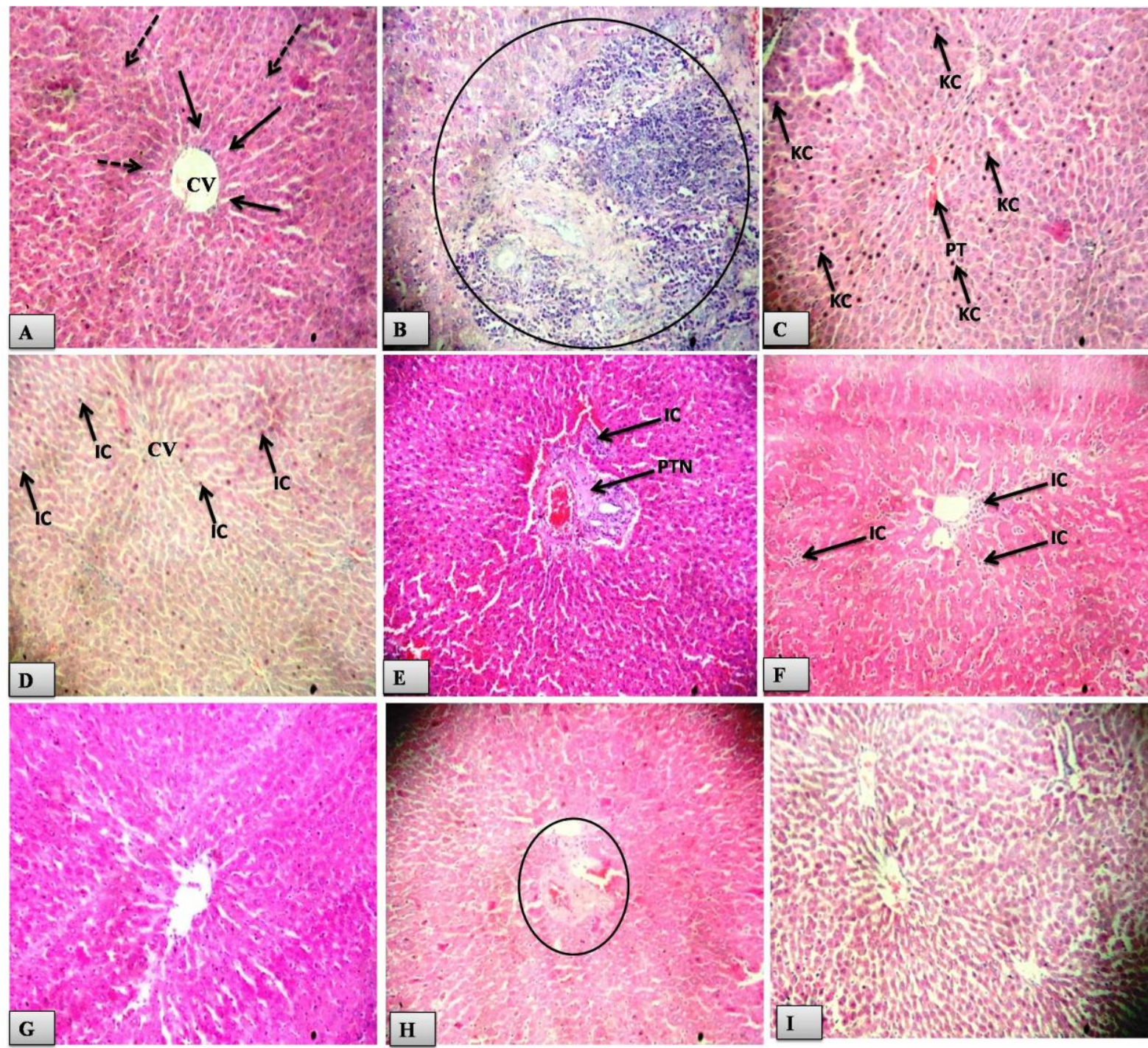

Group A (control) shows normal central vein= CV, with well radiating hepatocytes (dash arrow) and sinusoids (bold arrow).

Group B is characterized by mitotically active cells, inflammatory cells and periportal necrosis.

However, groups C, D, E and F show heavy infiltration of inflammatory cells (IC).

Group $\mathrm{H}$ shows degenerating and necrotic liver stroma (black circle), while

groups $\mathrm{G}$ and I are similar to the control (group A). H\&E x100 magnification.

Figure 1. Photomicrograph of the liver of experimental animals by treatment group

\section{DISCUSSION}

The present study showed the potentials of fractionalized extract of M. pudica in ameliorating the hepatocellular tumor induced by cadmium chloride in adult male Sprague Dawley rats. There was a significant $(\mathrm{p}<$
0.05) elevation in the values of serum AST, ALT, ALP and $\gamma \mathrm{GT}$ in group B when compared to the control group (Table 1). Increased values of serum AST and ALT have been attributed to any condition involving necrosis of hepatocytes, while increased serum ALP occur as a result of hepatobiliary diseases characterized by 
intra- or extrahepatic cholestasis among others. However, $\gamma$ GT are markedly increased in lesions which cause intrahepatic and/or extrahepatic obstruction of bile ducts, including liver diseases with a major cholestatic component. Lesser elevations of gamma-GT maybe seen in other liver diseases, while drugs causing hepatocellular degeneration and cholestasis may elevate the gamma-GT serum level (17). Our result is similar to that of Renugadevi and Prabu (18) and Kang et al. (19) where all liver specific enzymes were significantly elevated when induced with cadmium. The elevated enzyme reported in our current study corroborated with the histological findings of the hepatocellular tumor, which were basically characterized by mitotically active cells, inflammatory cells and periportal necrosis.

Once there is a damage to the liver, the injured endothelial cell obstruct capillary lumen and produce ischemia which may then initiate a number of molecular and cellular events that result in a subsequent activation of Kupffer cells, release of inflammatory mediators and recruitment of inflammatory cells, mainly polymorphonuclear neutrophils (PMN) and leukocytes (20). In the liver, the inflammatory cells accumulate in the sinusoid and adhere to endothelial cells $(20,21)$. Our result was further validated by a significant elevation of AFP tumor marker. Alpha fetoprotein is a marker of hepatocellular carcinoma and germ cell carcinoma (22). It has been reported to be the most useful in determining prognosis, diagnosis and management of hepatocellular carcinoma $(22,15)$. Elevated AFP levels indicate the presence of metastasis. Falling or rising AFP levels after therapy may determine the success or failure of the treatment regimen. A significant increase of AFP in patients considered free of metastatic tumor may indicate the development of metastasis (22).

Studies have revealed that cadmium exerts its toxic effects via oxidative damage to cellular organelles by inducing the generation of reactive oxygen species (ROS) $(23,24)$. ROS are capable of causing damage to biomolecules, including proteins, lipids, and nucleic acids, leading to cell and tissue injury. However, the mo- lecular mechanism of this process is not fully understood, but reports have shown that cadmium does it via an indirect phenomenon (25).

The level of serum liver specific enzymes (AST, ALT, ALP and $\gamma$ GT), hepatocellular carcinoma and germ cell carcinoma tumor marker (AFP) in the groups treated with different fractions of $M$. pudica leaf extract decreased significantly, especially with the high doses $(50 \mathrm{mg} / \mathrm{kg})$ of $\mathrm{n}$-hexane, butanol and aqueous fractions. These findings were supported by the histological architecture of slides $G$ and I (Figure 1), which were similar to the control in haematoxylin-stained sections when viewed under a light compound microscope. A significant decrease in the biochemical parameters level and the histological findings of our present study support previous conclusions (26-31) that M. Pudica has hepatoprotective and antioxidant effects. The hepatoprotective effect of $M$. Pudica has been attributed to the activities of its constituents like alkaloid, tannins, glycosides, terpenoids, flavonoids and saponins (31). Mimosine, which is a phytochemical component of $M$. Pudica, known to be a tyrosine, has the ability to chelate transition metals, such as $\mathrm{Fe}^{3+}(32)$ resulting in iron deficiency, which in turn could alter folate metabolism in mammals and interfere with tumor cell growth (33). Thus, these responses tend to inhibit an intense mitotic activity of cancer cells $(34,35)$.

\section{CONCLUSION}

The histological and biochemical findings of the present research demonstrated that n-hexane, butanol and aqueous fractions of M. pudica may have some anticarcinogenic activities, which was evident in the improvement of experimentally induced hepatocellular tumor in Sprague Dawley rats, decreasing the serum level of increased alpha-feto protein and gamma-glutamyl transferase. It is therefore recommended that a detailed molecular research on its mechanism of action, chemical constituent(s) and safe dose be carried out. 


\section{References}

1. Khan FA, Akhtar SS, Sheikh MK. Cancer Treatment - Objectives and Quality of Life Issues. The Malay J of Med Sc 2005; 12(1): 3-5.

2. Desai AG, Qazi GN, Ganju RK et al. Medicinal Plants and Cancer Chemoprevention. Current Drug Metabolism 2008; 9(7): 581-91. https://doi.org/10.2174/138920008785821657

3. Demain AL, Vaishnav P. Natural products for cancer chemotherapy. Microb Biotechnol 2011; 4(6): 68799.

\section{https://doi.org/10.1111/j.1751-7915.2010.00221.x}

4. Raven PH, Evert RF, Eichhorn SE. Physiology of Seed Plants: Plant Nutrition and Soils. Biology of Plants ( $7^{\text {th }}$ ed.). New York: W. H. Freeman and Company. 2005; 639: 978-7167.

5. Kishore RN, Sri AT, Anjaneyulu $\mathrm{N}$ et al. Study of the CNS activities of mimosa pudica linn. in animal model, Indo Am J P Sci, 2017; 4(03): 760-4.

6. Ahmed H, Sehgal S, Mishra A, et al. Mimosa Pudica L. (Laajvanti): an overview. Pharmacogn Rev 2012; 6: 115-24. https://doi.org/10.4103/0973-7847.99945

7. Yuan K, Liu JL, Yim MW. Chemical constituents of C-glycosylflavones from Mimosa pudica. Yao Xue B90 2006; 41: 435-8.

8. Onyije FM, Nwanze MC, Alade GO et al. Mimosa pudica Protects the Testes Against Cadmium-Induced Inflammation and Oligospermia: Potential Benefits in Treatment of Heavy Metal Toxicity. Pathophysiology 2018; 25; 293-7.

https://doi.org/10.1016/j.pathophys.2018.04.005

9. Pandey B, Husain N. Anti-microbial activity of Mimosa pudica L. against some microbes. Indian J Life Sci 2015; 5: 58-61.

10. Sia FY, Vejayan J, Januna A et al. Efficacy of tannins from Mimosa pudica and tannic acid in neutralizing cobra (Naja kaouthia) venom. J Venom Anim Toxins Incl Trop Dis 2011; 17: 42-8. https://doi.org/10.1590/S1678-91992011000100006

11. Malayan J, Selvaraj B, Warrier A et al. Anti- mumps virus activity by extracts of Mimosa Pudica, a unique Indian medicinal plant. Indian J Virol 2013; 24: 166-73.

https://doi.org/10.1007/s13337-013-0143-2

12. Kokane DD, More RY, Kale MB et al. Evaluation of wound healing activity of root of mimosa pudica. J Ethnopharmacol 2009; 124: 311-5. https://doi.org/10.1016/j.jep.2009.04.038

13. Kalabharathi HL, Shruthi SL, Vaibhari PS et al. Diuretic activity of ethanolic root extract of Mimosa pudica in albino rats. J Clin Diagn Res 2015; 9: 5-7.

14. Parmar F, Kushawaha N, Highland H et al. Invivo antioxidant and anticancer activity of Mimosa pudica L. extract and L-Mimosine on Lympoma Daudi cells. Int J Pharm Pharm Sci 2015; 7: 100-4.

15. Henry JB. Clinical Diagnosis and Management by Laboratory Methods. $19^{\text {th }}$ ed. Philadelphia: W.B. Saunders, 1996.

16. Onyije FM, Ngokere AA, Ligha AE et al. Computerassisted image analysis in the diagnosis of gynaecological lesions: A quantitative and comparative investigation of haematoxylin-eosin with special dyes on tissue. J Cancer Res Pract 2017; 4: 5-13. https://doi.org/10.1016/j.jcrpr.2016.11.002

17. Uthman ED. Interpretation of Lab Test Profiles. http://web2.airmail.net/uthman/lab_test.html.

[Access date: 2nd Oct., 2018]

18. Renugadevi J, Prabu SM. Cadmium induced hepatotoxicity in rats and the protective effect of naringenin. Exp Toxicol Pathol 2010; 62 (2):171-81. https://doi.org/10.1016/j.etp.2009.03.010

19. Kang MY, Cho SH, Lim YH et al. Effects of environmental cadmium exposure on liver function in 
adults. Occupational and environmental medicine 2003; 70(4):268-73.

https://doi.org/10.1136/oemed-2012-101063

20. Arroyo VS, Flores KM, Ortiz LB et al. Liver and Cadmium Toxicity. J Drug Metabol Toxicol 2012; S5:001.

21. Mousa SA Expression of adhesion molecules during cadmium hepatotoxicity. Life Sc 2004; 75: 93-105.

https://doi.org/10.1016/j.lffs.2003.12.010

22. Chan TM, Ho SK, Lai CL, Cheng IK et al. Lymphocyte subsets in renal allograft recipients with chronic hepatitis C virus infection. Nephrol Dial Transplant 1999; 14: 717-22.

https://doi.org/10.1093/ndt/14.3.717

23. Stohs SJ, Bagchi D, Hassoun E et al. Oxidative mechanisms in the toxicity of chromium and cadmium ions. J Environ Pathol Toxicol Oncol 2000; 20:77-88. https://doi.org/10.1615//EnvironPatholToxicolOncol. v20.i2.10

24. Henkler F, Brinkmann J, Luch A. The Role of Oxidative Stress in Carcinogenesis Induced by Metals and Xenobiotics. Cancers 2010 2(2): 376-96. https://doi.org/10.3390/cancers2020376

25. Watkin RD, Nawrot T, Potts RJ, et al. Mechanisms regulating the cadmium mediated suppression of Spl transcription factor activity in alveolar epithelial cells. Toxicology 2003; 18:157-78.

https://doi.org/10.1016/S0300-483X(02)00577-2

26. Khan MZ, Jogeza N, Tareen JK et al. Compilation on medicinal plants with hepatoprotective activity. Isra Med J 2016; 8: 196-202.

27. Kumaresan R, Veerakumar S, ElangoVA. Study on Hepatoprotective Activity of Mimosa pudica in Albino Rats. Int J of Pharma and Phytochem Res 2015; 7(2): 337-9.
28. Muhammad G, Hussain MA, Jantan I et al. Mimosa pudica L., a high-value medicinal plant as a source of bioactives for pharmaceuticals. Compr Rev Food Sci F 2006; 15: 303-15. https://doi.org/10.1111/1541-4337.12184

29. Rekha R, Hemachander R, Ezhilarasan T, et al. Phytochemical analysis and in-vitro antioxidant activity of Mimosa pudica L., leaves. Res J Pharm Tech 2010; 3(2):551-5.

30. Rajendran R, Hemalatha $S$, Akasakalai $K$ et al. Hepatoprotective activity of Mimosa pudica leaves against carbontetrachloride induced toxicity. J Nat Prod 2009; 2:116-22.

31. Aarthi N, Murugan K. Antimalarial activity and phytochemical screening of ethanolic leaf extract of Phyllanthus niruri and Mimosa pudica. IJPRD 2011; 3(3)24: 198 -205.

32. Linn HB, Falchetto R, Mosca PJ et al. Mimosine targets serine hydroxymethyltransferase. Biol Chem 1996; 271:2548-56.

https://doi.org/10.1074/jbc.271.5.2548

33. Gilbert DM, Neilson A, Miyazawa H et al. Influence of ferric chloride treated Leucaena leucocephala on metabolism of mimosine and 3-hydroxy-4 (1H)-pyridone in growing rabbits. Anim Feed Sci Technol 1998; 74:45-55.

https://doi.org/10.1016/S0377-8401(98)00172-2

34. Zalatnai A. P-glycoprotein expression is induced in human pancreatic xenografts during treatment with a cell cyclo regulator, mimosine. Pathol Oncol Res 2005;11: 164-69.

https://doi.org/10.1007/BF02893393

35. Mosca PJ, Dijkwel PA, Hamlin JL. The plant amino acid mimosine may inhibit initiation at origins of replication in Chinese hamster cells. Mol Cell Biol 1992; 12:4375-83.

https://doi.org/10.1128/MCB.12.10.4375 


\title{
Potencijal frakcionisanog ekstrakta biljke Mimosa pudica kao biljnog hemoterapeutika kod hepatocelularnog tumora izazvanog kadmijumom sa povišenim vrednostima alfa-fetoproteina i gama-glutamil transferaze
}

\author{
Onyije Felix Monday ${ }^{1}$, Newyear Patience Ekiokakpo르, Ezeiraku Ferdinand Chukwuma', \\ Mgbere Osaro Obari ${ }^{2}$
}

\begin{abstract}
${ }^{1}$ Departman za medicinska laboratorijaska istraživanja, Fakultet za bazične medicinske nauke, Koledž za zdravstvene nauke, Univerzitet Niger Delta, Ostrvo Vilberfors, Država Bajelsa, Nigerija

${ }^{2}$ Departman za farmaceutske zdravstvene ishode i politiku, Koledž za farmaciju, Univerzitet u Hjustonu, Medicinski centar u Teksasu, Hjuston, Teksas, Sjedinjene američke države
\end{abstract}

\section{SAŽETAK}

Istraživači su do sada opisali da biljka Mimosa pudica (M. pudica) poseduje i antiinflamatorna svojstva, dok su njena antikancerogena svojstva još uvek nedovoljno ispitana. Cilj ove studije bio je ispitivanje heksanske, butanolne i vodene frakcije ekstrakta lista M. pudica kao biljnog hemoterapeutika kod hepatocelularnog tumora izazvanog kadmijumom. Za potrebe ovog istraživanja korišćeno je 45 odraslih pacova soja Sprague Dawley. Pacovi su nasumično podeljeni u devet grupa (grupe A do I), pri čemu se svaka grupa sastojala od pet pacova. Hepatocelularni tumor bio je izazvan primenom kadmijuma u dozi od $0,4 \mathrm{mg} / \mathrm{ml}$, kroz pijaću vodu, u grupama $B$ do I, u trajanju od 50 dana. Frakcionisani ekstrakti biljke M. pudica davani su oralno u dozi od $25 \mathrm{mg} / \mathrm{kg}$ i $50 \mathrm{mg} / \mathrm{kg}$ grupama D i I u trajanju od 14 dana. U međuvremenu, grupa C primila je $2,5 \mathrm{mg} / \mathrm{kg}$ metoteroksata (uobičajeni lek za lečenje kancera) u narednih deset dana. Histološki slajdovi za grupe $C$ do I pokazali su značajni histomorfološki pomak $u$ tkivu jetre, kao i značajno smanjenje degeneracije u poređenju sa kontrolnom grupom (grupa B). Nivoi AST, ALT, ALP, $\gamma$ GT i AFP u grupi B (285,30 IU/1 $\pm 4.61 \mathrm{IU} / 1,137,30 \mathrm{IU} / 1 \pm 12.72 \mathrm{IU} / 1,424,70 \mathrm{IU} / 1 \pm$ $33,5 \mathrm{IU} / 1,6,80 \mathrm{IU} / 1 \pm 0,26 \mathrm{IU} / 1$ i $1,82 \mathrm{ng} / \mathrm{ml} \pm 0,28 \mathrm{ng} / \mathrm{ml}$ ) bili su značajno povećani u poređenju sa vrednostima

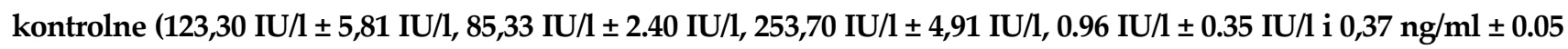
$\mathrm{ng} / \mathrm{ml}$ ) i drugih tretiranih grupa. Ova studija je pokazala da biljka Mimosa pudica poseduje moguća antikancerogena svojstva. Stoga se može koristiti u potencijalnoj biljnoj hemoterapiji.

Ključne reči: biljni hemoterapeutik, hepatocelularni tumor, Mimosa pudica, mitotički aktivna ćelija, kancer 